\title{
減算法による液体用流量計の校正の不確かさ*
}

\author{
嶋田隆司 ${ }^{* 1}$, 土井原良次 ${ }^{* 1}$ ，寺尾吉哉 ${ }^{* 1}$, 高本正樹 ${ }^{* 2}$
}

\section{Calibration Uncertainty of Flowmeters for Liquids by Using Subtraction Method}

\author{
Takashi SHIMADA ${ }^{* 1}$, Ryouji DOIHARA, Yoshiya TERAO and Masaki TAKAMOTO \\ ${ }^{* 1}$ National Institute of Advanced Industrial Science and Technology \\ 1-1-1 Umezono, Tsukuba-shi, Ibaraki, 305-8563 Japan
}

The calibration uncertainty of flowmeters using the subtraction method for hydrocarbon flow has been experimentally and analytically evaluated in order to calibrate flowmeters at lower flow rates than the flow rate range calibrated using the calibration facility. An expanded uncertainty is estimated to be $0.79 \%$ at the flow rate ratio of $1 / 100$ in the kerosene test rig of the primary standard facility. The main sources of combined uncertainty due to the subtraction method are the reproducibility of the standard flowmeters and the temperature measurements. Furthermore, a flowmeter has been calibrated using the subtraction method in order to verify uncertainty analysis. The result shows that the deviation of the calibrated flowmeter from the value using the primary standard agrees within the quoted expanded uncertainty.

Key Words : Flowmeter, Flow Measurement, Accuracy, Uncertainty, Subtraction Method, Calibration

\section{1. 緒言}

流量計による流量測定を精度良く行うためには，流量計を正確に校正することが求められる．また，計量トレ 一サビリティを確保するためには，国家標準から計量トレーサビリティが担保された標準により流量計を校正す るとともに，校正值に不確かさを付与することが必要である。標準となる流量計校正装置の流量範囲が限定され る場合には，校正された流量計を並列に接続することにより，標準となる流量を大きな流量へ拡大することがし ばしば行われる，一方，校正可能な流量範囲を小さな流量まで拡大するために，校正された 2 台の流量計を直列 に設置し, 流量計の間から分岐させた流路に流れる流量を 2 台の流量計から算出する流量の減算法が考えられる. 気体流量では音速ノズルの流出係数とスロート面積の積の比がノズルごとに一定であることを利用することによ り校正のための標準流量を小さくする方法が開発されている(1). また，減算された標準流量で流量計を校正する ことにより, 校正設備の不確かさ解析の妥当性を検証する方法が提唱されている(2). しかしながら, 流量の減算 法により流量計の校正の不確かさが増大寸ることが考えられるが，これまで十分な検討が行われていない.

そこで，本報では，石油類液体である灯油を対象流体とした流量の減算法によって，液体用流量計である容積 式流量計を校正する場合の校正の不確かさ(3)を詳細に解析した。ささらに, 国家標準である石油大流量校正設備(4)を 用いて減算法による流量計の校正值を算出することにより, 減算法に伴う不確かさの妥当性を実験的に検証した.

\section{2. 流量減算法による校正値の算出方法}

\section{$2 \cdot 1$ 流量減算法による校正方法}

流量減算法によって流量計を校正する場合の流量計の設置概略図を図 1 に示す. あらかじめ上位の標準器によ り校正された標準流量計 $\mathrm{A} ，$ 標準流量計Bを流れる流量值から流量計Xを通過する標準流量を算出し，流量計Xの

\footnotetext{
* 原稿受付 2012 年 1 月 13 日

*1 正員, 産業技術総合研究所（テ305-8563 茨城県つくば市梅園 1-1-1）

*2 正員, 元産業技術総合研究所

E-mail: t-shimada@aist.go.jp
} 
校正值を得る. 二重計時(5)を行うために，時間計が 3 台あり，それら全てに流量計Aから発信されるパルスが引き 込まれる. まず，流量，温度，圧力が安定したところで，流量計Aから発信されるパルスをトリガー信号として 流量計Aのパルス計数間隔時間計（Timer 1）及びパルス計数器（Pulse counter 1), 流量計Bのパルス計数間隔時間 計（Timer 2）及びパルス計数器（Pulse counter 2), 並びに流量計Xのパルス計数間隔時間計（Timer 3）及びパル ス計数器 (Pulse counter 3) が作動を開始する. 次に，流量計Aのパルス数が所定の数に達した時点でパルス計測 器などの作動を停止する. 本報では, 体積流量を対象とし, 校正される流量計は通過流量に比例した周波数のパ ルスを出力する型式に限定した.

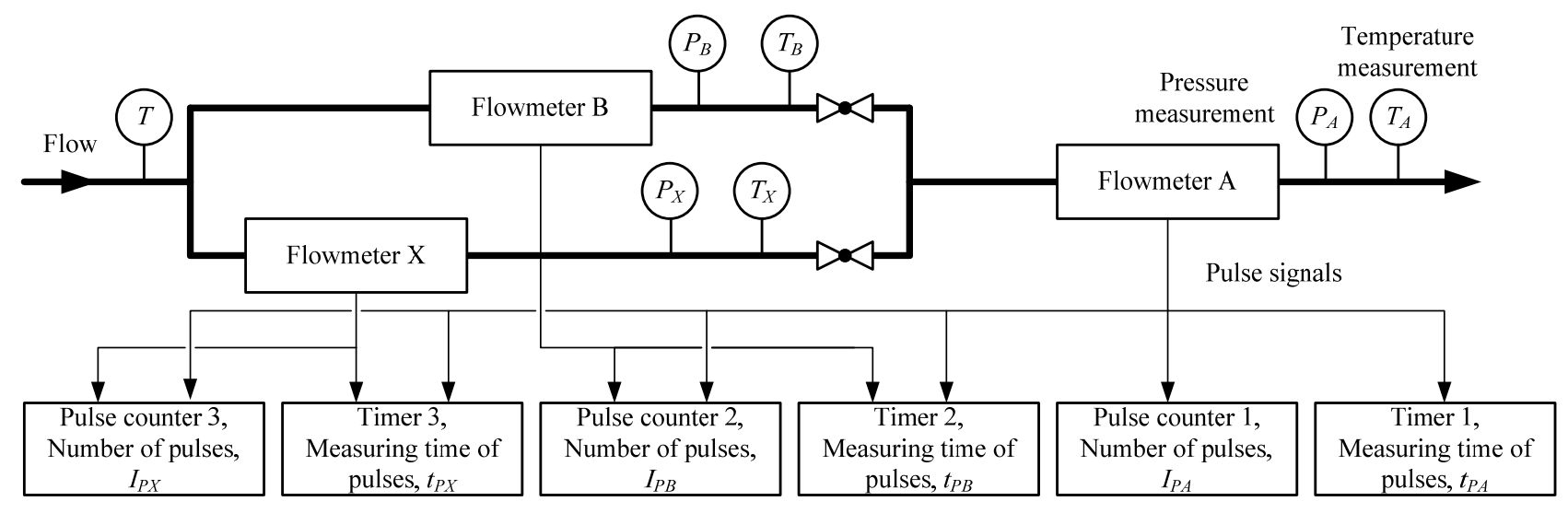

Fig. 1 Schematic of calibration for flowmeters using subtraction method.

\section{$2 \cdot 2$ 被校正流量計の校正係数（K 值）の算出}

流量計Aから流量計X及び流量計Bまでの管路に試験液の漏れ，気相の発生及び減少がないと仮定すると，流量 計 $\mathrm{A}$, 流量計X及び流量計Bをそれぞれ通過する試験液の質量流量の計測時間 $t_{D}(\mathrm{~s})$ で時間平均值 $\overline{Q_{A}}(\mathrm{~kg} / \mathrm{s}), \overline{Q_{B}}$ $(\mathrm{kg} / \mathrm{s}), \overline{Q_{X}}(\mathrm{~kg} / \mathrm{s})$ の間には質量保存の法則により, 式(1)が成立する.

$$
\overline{Q_{A}} \cdot t_{D}=\overline{Q_{B}} \cdot t_{D}+\overline{Q_{X}} \cdot t_{D}+\Delta M_{L D V}
$$

ここで， $\Delta M_{L D V}(\mathrm{~kg})$ は流量計 $\mathrm{A} ， \mathrm{~B} ， \mathrm{X}$ 間の接続管路内の質量変化量を意味する．さらに，流量計Aを通過する 質量流量の時間平均值 $\overline{Q_{A}}(\mathrm{~kg} / \mathrm{s})$ は, 計測時間で時間平均された密度 $\overline{\rho_{A}}\left(\mathrm{~kg} / \mathrm{m}^{3}\right)$ と体積流量の時間平均値 $\overline{q_{A}}$ $\left(\mathrm{m}^{3} / \mathrm{s}\right)$ との積, 及び流量と密度変動の相関に伴う影響分 $\Delta\left(\rho_{A} q_{A}\right)(\mathrm{kg} / \mathrm{s})$ に分けられ, 式(2)で表される.

$$
\overline{Q_{A}}=\overline{\rho_{A}} \overline{q_{A}}+\Delta\left(\rho_{A} q_{A}\right)
$$

流量計 $\mathrm{A}$ と同様に，流量計B及び流量計Xを通過する質量流量の時間平均值 $\overline{Q_{B}}(\mathrm{~kg} / \mathrm{s}), \overline{Q_{X}}(\mathrm{~kg} / \mathrm{s})$ はそれぞれ， 計測時間で時間平均された密度 $\overline{\rho_{B}}\left(\mathrm{~kg} / \mathrm{m}^{3}\right), \overline{\rho_{X}}\left(\mathrm{~kg} / \mathrm{m}^{3}\right)$ と体積流量の時間平均值 $\overline{q_{B}}\left(\mathrm{~m}^{3} / \mathrm{s}\right), \overline{q_{X}}\left(\mathrm{~m}^{3} / \mathrm{s}\right)$ との積, 及び流量と密度変動の相関に伴う影響分 $\Delta\left(\rho_{B} q_{B}\right)(\mathrm{kg} / \mathrm{s}), \Delta\left(\rho_{X} q_{X}\right)(\mathrm{kg} / \mathrm{s})$ に分けられ，式(3)(4)で表される.

$$
\begin{aligned}
& \overline{Q_{B}}=\overline{\rho_{B}} \overline{q_{B}}+\Delta\left(\rho_{B} q_{B}\right) \\
& \overline{Q_{X}}=\overline{\rho_{X}} \overline{q_{X}}+\Delta\left(\rho_{X} q_{X}\right)
\end{aligned}
$$

式(1)〜(4)より流量計Xを通過する体積流量の時間平均值 $\overline{q_{X}} \quad\left(\mathrm{~m}^{3} / \mathrm{s}\right)$ は式(5)で表される.

$$
\overline{q_{X}}=\frac{\overline{\rho_{A}}}{\overline{\rho_{X}}} \overline{q_{A}}-\frac{\overline{\rho_{B}}}{\overline{\rho_{X}}} \overline{q_{B}}+\frac{\Delta\left(\rho_{A} q_{A}\right)-\Delta\left(\rho_{B} q_{B}\right)-\Delta\left(\rho_{X} q_{X}\right)}{\overline{\rho_{X}}}-\frac{\Delta M_{L D V}}{\overline{\rho_{X}} t_{D}}
$$


式(5)の右辺第 3 項及び第 4 項に相当する流量と密度変動の相関に伴う影響分の補正, 並びに接続管路内の質量 変化の補正を行わないものとすると, 流量計Xを通過する体積流量の時間平均值 $\overline{q_{X}}$ は式(6)から求められる.

$$
\overline{q_{X}}=\frac{\overline{\rho_{A}}}{\overline{\rho_{X}}} \overline{q_{A}}-\frac{\overline{\rho_{B}}}{\overline{\rho_{X}}} \overline{q_{B}}
$$

流量計 $\mathrm{A} ，$ 流量計B及び被校正流量計Xを通過する体積流量の時間平均值 $\overline{q_{A}}, \overline{q_{B}}, \overline{q_{X}}$ はそれぞれ式(7)〜(9)で 表される.

$$
\begin{aligned}
& \overline{q_{A}}=\frac{f_{P A}}{1000 K_{f A}}=\frac{I_{P A}}{1000 t_{P A} K_{f A}} \\
& \overline{q_{B}}=\frac{f_{P B}}{1000 K_{f B}}=\frac{I_{P B}}{1000 t_{P B} K_{f B}} \\
& \overline{q_{X}}=\frac{f_{P X}}{1000 K_{f X}}=\frac{I_{P X}}{1000 t_{P X} K_{f X}}
\end{aligned}
$$

ここで, $K_{f A}$ (pulse/L), $K_{f B}$ (pulse/L)は, それぞれ流量計 X の校正条件での流量計 A, 流量計 B の校正係数 (K 值）であり, $K_{f X}$ (pulse/L)は減算法により得られる流量計 $\mathrm{X}$ の校正係数（K 值）である. また, $f_{p A}$ (pulse/s), $f_{p B}$ (pulse/s), $f_{p X}$ (pulse/s) は流量計 $\mathrm{A}$, 流量計 $\mathrm{B}$, 流量計 $\mathrm{X}$ のパルス発信周波数である.さらに, $t_{p A}(\mathrm{~s}), t_{p B}$ $(\mathrm{s}), t_{p X}(\mathrm{~s})$ は流量計 $\mathrm{A}$, 流量計 $\mathrm{B}$, 流量計 $\mathrm{X}$ のパルス計数時間であり， $I_{p A}$ (pulse) は時間 $t_{p A}$ にパルスカウンタ により積算された流量計 $\mathrm{A}$ のパルス数, $I_{p A}$ (Pulse)は時間 $t_{p B}$ に積算された流量計 B のパルス数, $I_{p X}$ (Pulse) は時間 $t_{p X}$ に積算された流量計 $\mathrm{X}$ のパルス数を意味する.

式(6)〜(9)より被校正流量計XのK值 $K_{f X}$ は式(10)で表される.

$$
K_{f X}=\frac{1}{\left(\frac{1}{K_{f A}} \frac{\overline{\rho_{A}}}{\rho_{X}} \frac{t_{P X}}{t_{P A}} \frac{I_{P A}}{I_{P X}}-\frac{1}{K_{f B}} \frac{\overline{\rho_{B}}}{\overline{\rho_{X}}} \frac{t_{P X}}{t_{P B}} \frac{I_{P B}}{I_{P X}}\right)}
$$

流量計Aと流量計Xを通過する試験液の密度比 $\overline{\rho_{A}} / \overline{\rho_{X}}$ 及び流量計Bと流量計Xの密度比 $\overline{\rho_{B}} / \overline{\rho_{X}}$ はそれぞれ式 (11)(12)で表される.

$$
\begin{aligned}
& \frac{\overline{\rho_{A}}}{\overline{\rho_{X}}}=1+\frac{\alpha_{L}}{\overline{\rho_{X}}}\left(T_{A}-T_{X}\right)+\beta_{L}\left(p_{A}-p_{X}\right) \\
& \frac{\overline{\rho_{B}}}{\overline{\rho_{X}}}=1+\frac{\alpha_{L}}{\overline{\rho_{X}}}\left(T_{B}-T_{X}\right)+\beta_{L}\left(p_{B}-p_{X}\right)
\end{aligned}
$$

ここで, $\alpha_{L}\left(\mathrm{~kg} /\left(\mathrm{m}^{3} \mathrm{~K}\right)\right), \quad \beta_{L}\left(\mathrm{MPa}^{-1}\right)$ はそれぞれ温度に対する密度の感度係数 (熱膨張係数), 圧力に対する密度 の感度係数 (圧縮率) であり， $T_{A}\left({ }^{\circ} \mathrm{C}\right), T_{B}\left({ }^{\circ} \mathrm{C}\right), T_{X}\left({ }^{\circ} \mathrm{C}\right)$ はそれぞれ流量計 $\mathrm{A}$, 流量計 B 及び流量計 $\mathrm{X}$ での試 験液温度， $p_{A}(\mathrm{MPa}), p_{B}(\mathrm{MPa}), p_{X}(\mathrm{MPa})$ は流量計 $\mathrm{A}$ ，流量計 $\mathrm{B}$ 及び流量計 $\mathrm{X}$ での圧力を意味する.

また, 流量計 $\mathrm{X}$ の $\mathrm{K}$ 值の測定結果は, $N$ 回の繰り返し測定により $i$ 番目に得られた校正值 $K_{f X, i}$ を相加平均 した平均 $\mathrm{K}$ 值 $\left\langle K_{f X}\right\rangle$ (pulse/L)である. 


$$
\left\langle K_{f X}\right\rangle=\frac{\sum_{i}^{N} K_{f X, i}}{N}
$$

\section{3. 流量減算法による流量計の校正の実例}

\section{$3 \cdot 1$ 実験方法}

石油大流量校正設備(4)には灯油及び軽油の 2 種類の液種に対する試験ラインがあり, 試験流量によって秤量計 を選択し，流量が $30 \sim 300 \mathrm{~m}^{3} / \mathrm{h}$ では $10 \mathrm{t}$ 科量システムを，また流量が $3 \sim 30 \mathrm{~m}^{3} / \mathrm{h}$ では $1 \mathrm{t}$ 科量システムを使用す る. 体積流量計の校正の相対拡張不確かさ（包含係数 $k=2$ ） は $0.030 \%$ あ゙あ ${ }^{(5)}$. 本報で行った流量減算法によ る流量計を校正する場合の流量計の設置概略図を図 2 に示寸．流量計として表 1 に示寸上流配管構成の影響を受 けにくい容積流量計を使用した。実験条件を表 2 に示す。 まず，流量計A及び流量計Bを灯油試験ラインの $10 \mathrm{t}$ 科量システムを用いて $275 \sim 298 \mathrm{~m}^{3} / \mathrm{h}$ 流量で校正した，次に，並列に設置された流量計Bと流量計X1 及びX2に 流れる流量比を変えて流量計X1 及びX2 を校正した。 流量計X1 及びX2 の校正值は, 流量計Aを流れる流量（298 $\left.\mathrm{m}^{3} / \mathrm{h}\right)$ から流量計Bでの流量（275 $295 \mathrm{~m}^{3} / \mathrm{h} ）$ を減算した標準流量值（3 $23 \mathrm{~m} / \mathrm{h} ）$ を用いて算出した. さらに, 減算法の妥当性を検討するために流量計X1 及び流量計X2 を $1 \mathrm{t}$ 秤量システムで校正した. 可能な限り, 理想的な 条件で減算法による流量計の校正を行い, 減算法に伴う不確かさの増大を抑制した. 試験液温度は $20{ }^{\circ} \mathrm{Cであり,}$

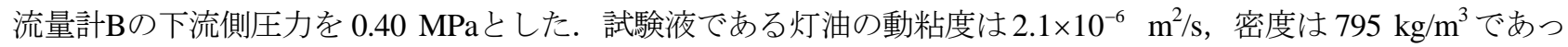
た.

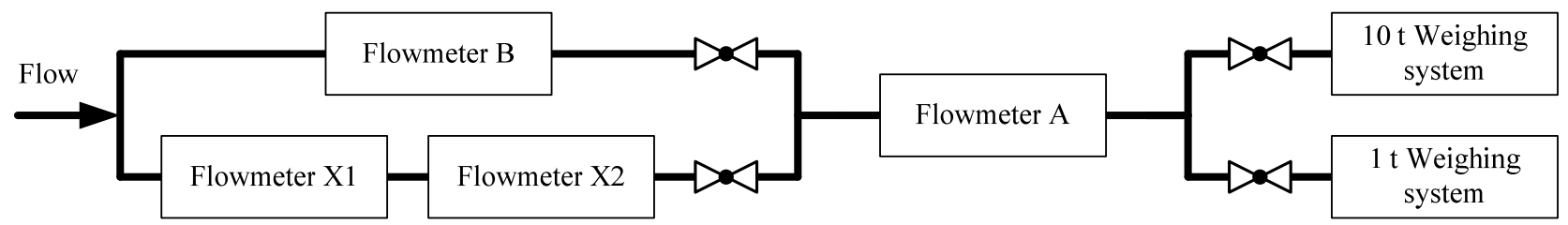

Fig. 2 Schematic of calibration

Table 1 Flowmeters

\begin{tabular}{|l|l|l|l|}
\hline Flowmeter & Type & Diameter & Flow rate range \\
\hline Flowmeter A & Servo PD meter & $150 \mathrm{~mm}$ & $\sim 300 \mathrm{~m}^{3} / \mathrm{h}$ \\
\hline Flowmeter B & PD meter & $150 \mathrm{~mm}$ & $\sim 300 \mathrm{~m}^{3} / \mathrm{h}$ \\
\hline Flowmeter X1 & PD meter & $50 \mathrm{~mm}$ & $\sim 30 \mathrm{~m}^{3} / \mathrm{h}$ \\
\hline Flowmeter X2 & PD meter & $50 \mathrm{~mm}$ & $\sim 30 \mathrm{~m}^{3} / \mathrm{h}$ \\
\hline
\end{tabular}

Table 2 Experimental condition

\begin{tabular}{|c|c|c|c|}
\hline $\begin{array}{c}\text { Total flow rate at } \\
\begin{array}{c}\text { Flowmeter A } \\
\left(\mathrm{m}^{3} / \mathrm{h}\right)\end{array}\end{array}$ & $\begin{array}{c}\text { Flowrate at Flowmeter B } \\
\left(\mathrm{m}^{3} / \mathrm{h}\right)\end{array}$ & $\begin{array}{c}\text { Flowrate at Flowmeter X1\&X2 } \\
\left(\mathrm{m}^{3} / \mathrm{h}\right)\end{array}$ & $\begin{array}{c}\bar{q}_{\mathrm{X}} \\
\overline{q_{\mathrm{A}}}\end{array}$ \\
\hline \multirow{2}{*}{298} & 295 & 3 & 0.01 \\
\cline { 2 - 4 } & 292 & 6 & 0.02 \\
\cline { 2 - 4 } & 275 & 23 & 0.08 \\
\hline
\end{tabular}

\section{$3 \cdot 2$ 参照流量計の校正結果}

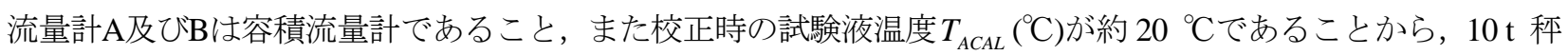
量システムによる校正により得られた流量計 $\mathrm{A} の \mathrm{~K}$ 值 $K_{\mathrm{fACAL}} \quad(\mathrm{pulse} / \mathrm{L})$ は, 流量計内回転子の材質の線膨張係数 
$\alpha_{F M}\left(\mathrm{~K}^{-1}\right)$, 及び流量計 $\mathrm{A} の$ 校正時の試験液温度 $T_{A C A L}\left({ }^{\circ} \mathrm{C}\right)$ を用いて式(14)より $20{ }^{\circ} \mathrm{C}$ 基準のK值 $K_{f A 20}(\mathrm{pulse} / \mathrm{L})$ に 換算された.

$$
K_{\text {fA20 }}=K_{\text {fACAL }}\left(1+3 \alpha_{F M}\left(T_{A C A L}-20\right)\right)
$$

10 t科量システムで校正された流量計 $\mathrm{A}$ と流量計 $\mathrm{B} の 20{ }^{\circ} \mathrm{C}$ 基準のK值をパルス周波数に対してプロットしたも のを図 3 に示寸。流量計Aと流量計Bの近似曲線式 $K_{f A 20, f i t}, K_{f B 20, f i t}(p u l s e / L)$ とて, それぞれの流量計から発信 されるパルス周波数 $f_{P A}, f_{P B}$ (pulse/s) に対するK 值の関数形（1 次式）を $20{ }^{\circ} \mathrm{C}$ 基準のK值 $K_{f A 20}, K_{f B 20}$ に最小 二乗法によりあてはめて式(15), (16)を得た.

$$
\begin{aligned}
& K_{f A 20, f i t}=1.140029 \times 10^{-5} f_{P A}+1.903322 \\
& K_{f B 20, f i t}=-8.593325 \times 10^{-6} f_{P B}+8.846259
\end{aligned}
$$

さらに, 減算法による流量計 $\mathrm{X} 1$ 及び流量計 $\mathrm{X} 2$ 校正時の流量計 $\mathrm{A}$ の試験液温度 $T_{\mathrm{A}}\left({ }^{\circ} \mathrm{C}\right)$ における流量計 $\mathrm{A} の \mathrm{~K}$ 值 $K_{f A}$ は式(17)より得られ, 流量計BのK值 $K_{f B}$ も流量計 $\mathrm{A}$ と同様の方法で得た.

$$
K_{f A}=K_{f A 20, f i t}\left(1+3 \alpha_{F M}\left(20-T_{A}\right)\right)
$$

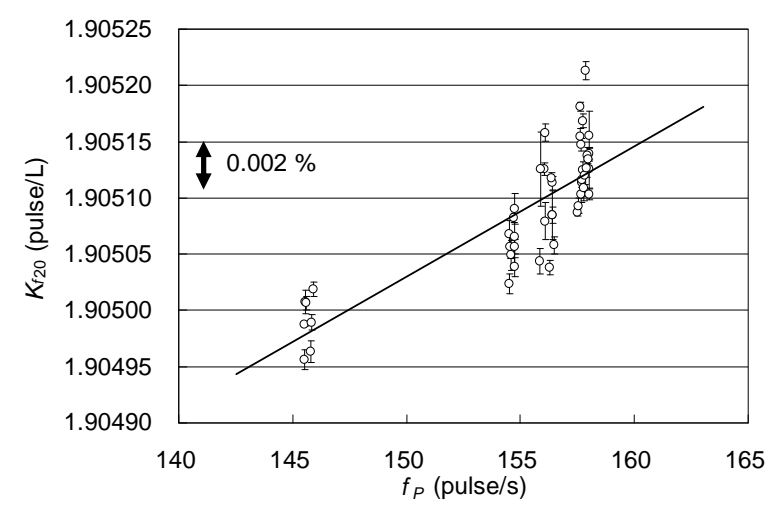

(a)

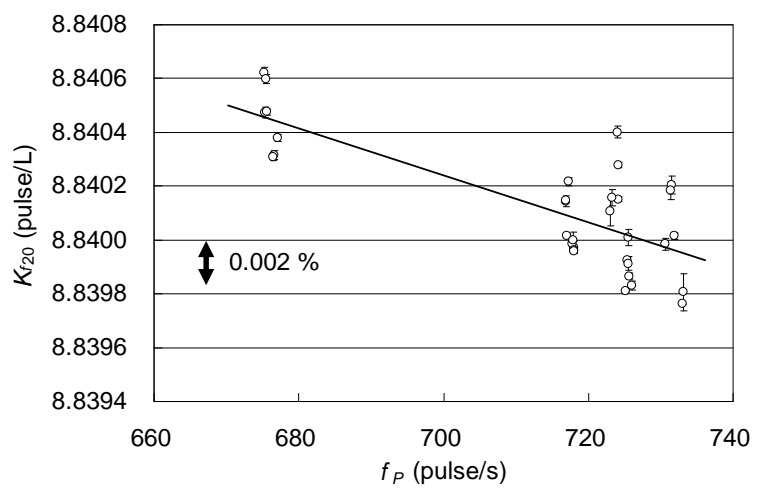

(b)

Fig. $3 \mathrm{~K}$ factors obtained using the $10 \mathrm{t}$ weighing system of the primary standard. (a) flowmeter $\mathrm{A}$, (b) flowmeter $\mathrm{B}$. Each marker represents a mean value of reputation measurements at the same day. Error bars indicate the experimental standard deviation of the mean. The solid lines indicate Eqs.(15), (16).

\section{$3 \cdot 3$ 減算法による流量計の校正結果}

流量計A及びBを用いた流量減算法により得られた流量計X1 及びX2 のK值 $K_{f X 1}$ (pulse/L), $K_{f X 2}$ (pulse/L)は, (14)式を用いて $20^{\circ} \mathrm{C}$ 基準のK值 $K_{f \times 1,20}$ （pulse/L)， $K_{f \times 2,20}$ （pulse/L)に換算された. $1 \mathrm{t}$ 科量システムで校正した流量 計X1 及びX2 の $20{ }^{\circ} \mathrm{C}$ 基準のK值 $K_{f x 1,20 w s}$ (pulse/L), $K_{f x 2,20 w s}$ （pulse/L)に対する流量減算法により得たK值 $K_{f x 1,20}$, $K_{f x 2,20}$ の相対偏差を図 4 に示寸. ここで， $K_{f X 1, n o m}$ (pulse/L)， $K_{f X 2, n o m}$ (pulse/L)はそれぞれ流量計X1 及びX2 の公 称K值を意味する. また, 図 4 中のプロットは, 繰り返し測定により得られた同一日での平均值であり, 誤差棒 は平均の実験標準偏差を表す。 $\overline{q_{X}}=23 \mathrm{~m}^{3} / \mathrm{h}\left(\overline{q_{X}} / \overline{q_{A}}=0.08\right)$ では, 流量計X1 及びX2 のK值の相対偏差は $\pm 0.05 \%$ 以下であり, ほぼ一致していることがわかる。一方, 校正流量が小さくなる, すなわち流量比 $\left(\overline{q_{X}} / \overline{q_{A}}\right)$ が小さ くなるにつれて, 繰り返し測定に伴うばらつきが大きくなる. また, $6 \mathrm{~m}^{3} / \mathrm{h}\left(\overline{q_{X}} / \overline{q_{A}}=0.02\right)$ 及び $3 \mathrm{~m}^{3} / \mathrm{h}\left(\overline{q_{X}} / \overline{q_{A}}=0.01\right)$ では，K值の相対偏差が約 $\pm 0.3 \%$ となることがわかる．さらに，日内変動に起因する実験標準偏差に比べ，日間 
変動による偏差が大きいことは，流量計等の日間変動（再現性）に起因する不確かさ要因が校正の不確かさに大 きく影響を及ぼしていることを示唆する.

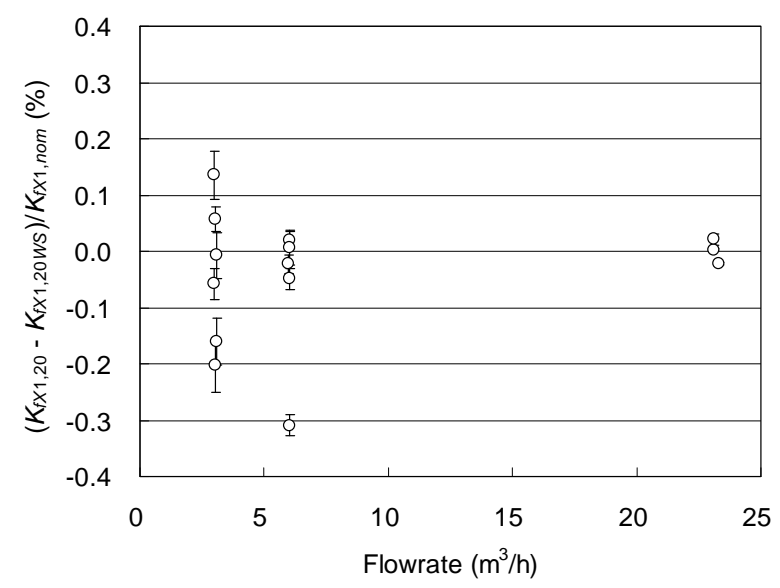

(a)

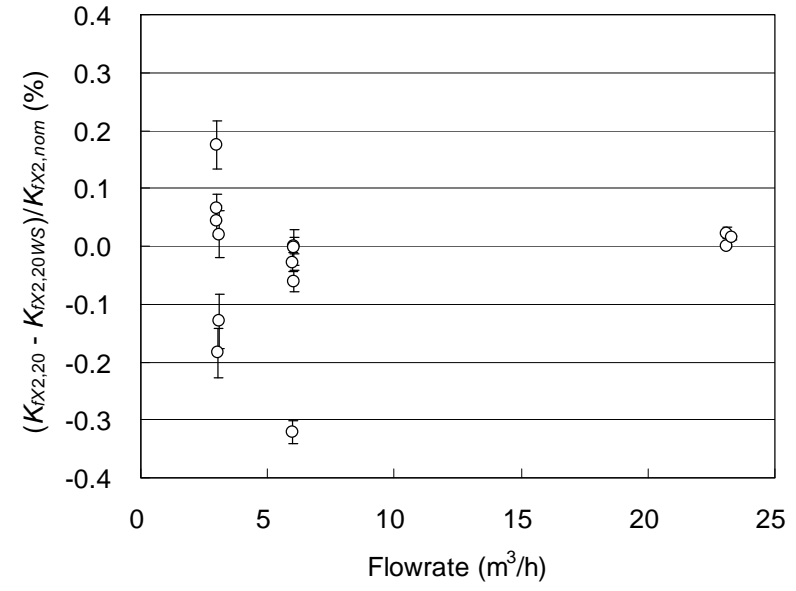

(b)

Fig. 4 Difference of $\mathrm{K}$ factors from the values obtained using the $1 \mathrm{t}$ weighing system of the primary standard. (a) flowmeter X1, (b) flowmeter X2. Each marker represents a mean value of reputation measurements. Each error bar indicates an experimental standard deviation of the mean.

$1 \mathrm{t}$ 㷏量システムで得られた流量計X2 のK值に対する減算法により得たK 值の相対偏差を, 同時に校正した流量 計X1の相対偏差に対してプロットしたものを図 5 に示す. 図 5 は一般にYouden プロットと呼ばれ(7), 同時に校 正された二つの流量計の校正值に正の相関がある場合(第 1 及び第 3 象限に分散した場合) には，校正值のばら つきは標準流量を発生させる校正設備に起因する。それに対し，校正值に相関が現れない場合には，K 值の分散 は流量計もしくは完全に相関されない要因によると言われている. 図 5 より, 校正值は系統的偏差が見られ, 2 種 類の流量計の校正值には強い正の相関があると言える。このことは，流量計X1 及びX2 の偏差は主に減算法によ って算出される標準流量の偏差によって生じたことを示唆する.したがって，校正の不確かさを小さくするため には，被校正流量計を通過する標準流量を正確に算出する必要性があることがわかった.

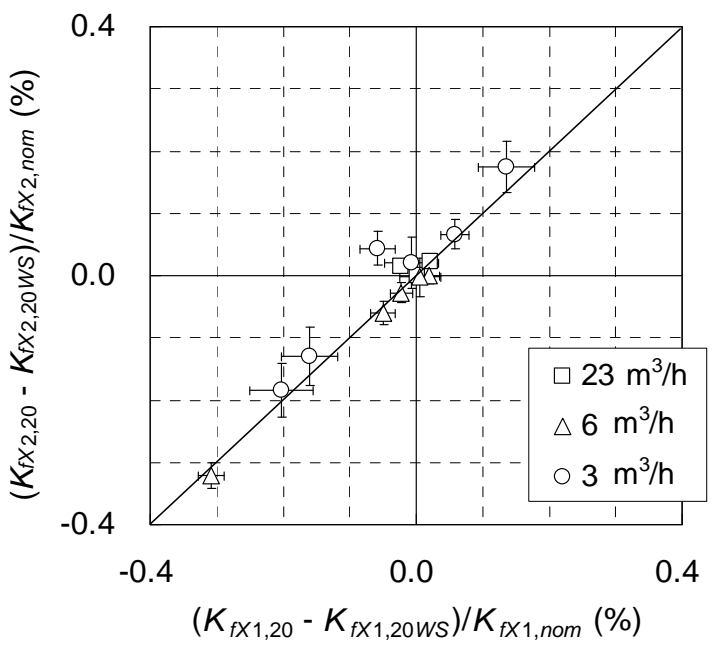

Fig. 5 Variation in K-factors of the flowmeter X2 against those of the flowmeter X1. Each error bar indicates the experimental standard deviation of the mean. 


\section{4. 流量減算法による測定の不確かさの推定}

前章で述べた実験条件及び測定結果に基づいて, 流量計 X1 及び X2 の校正の不確かさを評価した. 校正の不確 かさに寄与するすべての要因を検証することは非常に困難である，そこで，流量減算法を用いた測定の不確かさ の推定では，流量計 $\mathrm{A}$ から流量計 B 及び被校正流量計 X1 及び X2 までの管路に試験液の漏れがなく，また気相 の増減がないと見なした．また，流量変動によって流量計の特性は変化せずに，流量計から流量計内を通過する 瞬時流量に比例した周波数でパルスが発信されると見なした.

\section{$4 \cdot 1$ 不確かさ解析のためのモデル式}

被校正流量計XのK值 $\left\langle K_{f X}\right\rangle$ (pulse/L)の不確かさ解析のためのモデル式は式(18)で表される.

$$
\left\langle K_{f X}\right\rangle=K_{f X}+\delta\left\langle K_{f X}\right\rangle
$$

$\delta\left\langle K_{f X}\right\rangle$ (pulse/L)は, 校正時に生じる被校正流量計Xの偶然効果による偏差である. 被校正流量計Xのパルス計

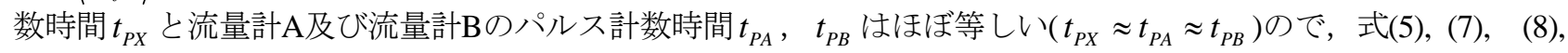
(18)より，不確かさ解析のためのモデル式として式(19)が導かれる.

$$
\begin{aligned}
\left\langle K_{f X}\right\rangle= & \frac{1}{\left(\frac{1}{K_{f A}} \frac{\overline{\rho_{A}}}{\rho_{X}} \frac{t_{P X}}{t_{P A}} \frac{I_{P A}}{I_{P X}}-\frac{1}{K_{f B}} \frac{\overline{\rho_{B}}}{\overline{\rho_{X}}} \frac{t_{P X}}{t_{P B}} \frac{I_{p B}}{I_{P X}}\right)}-K_{f X} \frac{\Delta\left(\rho_{A} q_{A}\right)-\Delta\left(\rho_{B} q_{B}\right)-\Delta\left(\rho_{X} q_{X}\right)}{\overline{\rho_{X}} \bar{q}_{X}} \\
& +K_{f X} \frac{\Delta M_{L D V}}{\overline{\rho_{X}} \frac{q_{X}}{q_{D}}}-\delta\left\langle K_{f X}\right\rangle
\end{aligned}
$$

\section{$4 \cdot 2$ 被校正流量計の校正の不確かさ}

流量計から発信されるパルスは寸べて取得されることが考えられることから，パルス数に伴う不確かさは零で あると推定した．したがって，式(19)を展開すると，被校正流量計XのK值の相対合成標準不確かさは式(20)で表 される。

$$
\begin{aligned}
& \left\{\frac{u_{c}\left(\left\langle K_{f X}\right\rangle\right)}{\left\langle K_{f X}\right\rangle}\right\}^{2}=\left\{\frac{\overline{q_{A}}}{\overline{q_{X}}}\right\}^{2}\left\{\frac{u\left(K_{f A}\right)}{K_{f A}}\right\}^{2}+\left\{\frac{\overline{q_{B}}}{\overline{q_{X}}}\right\}^{2}\left\{\frac{u\left(K_{f B}\right)}{K_{f B}}\right\}^{2}-2 \frac{\overline{q_{A}}}{\overline{q_{X}}} \frac{\overline{q_{B}}}{\overline{q_{X}}} r\left\{\frac{1}{K_{f A}}, \frac{1}{K_{f B}}\right\}\left\{\frac{u\left(K_{f A}\right)}{K_{f A}}\right\}\left\{\frac{u\left(K_{f B}\right)}{K_{f B}}\right\} \\
& +u^{2}\left(\frac{\overline{q_{A}}}{\overline{q_{X}}} \frac{\overline{\rho_{A}}}{\overline{\rho_{X}}}-\frac{\overline{q_{B}}}{\overline{q_{X}}} \frac{\overline{\rho_{B}}}{\overline{\rho_{X}}}\right)+u^{2}\left(\frac{\overline{\underline{q_{A}}}}{\overline{q_{X}}} \frac{t_{p X}}{t_{p A}}-\frac{\overline{q_{B}}}{\overline{q_{X}}} \frac{t_{p X}}{t_{p B}}\right) \\
& +\left\{\frac{u\left(\Delta\left(\rho_{A} q_{A}\right)-\Delta\left(\rho_{B} q_{B}\right)-\Delta\left(\rho_{X} q_{X}\right)\right)}{\overline{\rho_{X}} q_{X}}\right\}^{2}+\left\{\frac{\overline{q_{A}}}{\overline{q_{X}}}\right\}^{2}\left\{\frac{u\left(\Delta M_{L D V}\right)}{\overline{\rho_{A} q_{A}} t_{D}}\right\}^{2}+\left\{\frac{u\left(\delta\left\langle K_{f X}\right\rangle\right)}{\left\langle K_{f X}\right\rangle}\right\}^{2}
\end{aligned}
$$

ここで, $\mathrm{GUM}^{(3)}$ の記述方法に従い, $u_{c}\left(\left\langle K_{f x}\right\rangle\right)$ はK 值 $\left\langle K_{f x}\right\rangle$ の合成標準不確かさを表し, $u$ は各不確かさ要素 の標準不確かさを表す. また, $r\{x, y\}$ は $x$ 及び $y$ の相関係数であり, 式(20)の右辺第 $1 \sim 3$ 項は流量計に伴う不確 かさ, 右辺第 4 8 項はそれぞれ密度測定, 時間計測, 流量変動と密度変動の相関, 接続管路内の質量変化, 流量 計Xの偶然効果による寄与を意味する.また，式(20)中の $\overline{q_{A}}, \overline{q_{B}}, \overline{q_{X}}$ は入力值ではなく係数として扱う.

\section{$4 \cdot 3$ 流量計の K 值に伴う不確かさ}

減算法による流量計Xの校正時における流量計BのK值の不確かさ解析のためのモデル式は式(21)で表される. 


$$
\begin{aligned}
K_{f B} & =K_{f B 20, f i t}\left(1+3 \alpha_{F M}\left(20-T_{B}\right)\right)+\delta K_{f B, R P R}+\delta K_{f B, p}+\delta K_{f B, v}+\delta K_{f B} \\
& =K_{f B C A L}\left(1+3 \alpha_{F M}\left(T_{B C A L}-20\right)+\delta K_{f B, L N R}\right)\left(1+3 \alpha_{F M}\left(20-T_{B}\right)\right)+\delta K_{f B, R P R}+\delta K_{f B, p}+\delta K_{f B, v}+\delta K_{f B} \\
& \approx K_{f B C A L}\left(1+3 \alpha_{F M}\left(T_{B C A L}-T_{B}\right)\right)+\delta K_{f B, L N R}+\delta K_{f B, R P R}+\delta K_{f B, p}+\delta K_{f B, v}+\delta K_{f B}
\end{aligned}
$$

$\delta K_{f B, L N R}$ (pulse/L), $\delta K_{f B, R P R} \quad(\mathrm{pulse} / \mathrm{L}), \delta K_{f B, p} \quad$ (pulse/L), $\delta K_{f B, v} \quad$ (pulse/L)， $\delta K_{f B} \quad$ (pulse/L)は，それぞれ直線性 に起因寸る補正值，校正周期間で生じる経年変化（再現性）に起因寸る補正值，測定圧力に起因寸る補正值，試 験液物性に起因寸る補正值，及び流量計の繰り返し性（偶然効果）を意味する．流量計AのK值の不確かさ解析の ためのモデル式も式(21)と同様のモデル式で表される，式(21)を展開すると，流量計BのK值の相対合成標準不確 かさは式(22)で表される.

$$
\begin{aligned}
\left\{\frac{u\left(K_{f B}\right)}{K_{f B}}\right\}^{2} & =\left\{\frac{u\left(K_{f B C A L}\right)}{\left\langle K_{f B}\right\rangle}\right\}^{2}+\left(3 \alpha_{F M}\right)^{2} u^{2}\left(T_{B C A L}-T_{B}\right)+\left\{3\left(T_{B C A L}-T_{B}\right)\right\}^{2} u^{2}\left(\alpha_{F M}\right) \\
& +\left\{\frac{u\left(\delta K_{f B, L N R}\right)}{\left\langle K_{f B}\right\rangle}\right\}^{2}+\left\{\frac{u\left(\delta K_{f B, R P R}\right)}{\left\langle K_{f B}\right\rangle}\right\}^{2}+\left\{\frac{u\left(\delta K_{f B, p}\right)}{\left\langle K_{f B}\right\rangle}\right\}^{2}+\left\{\frac{u\left(\delta K_{f B, v}\right)}{\left\langle K_{f B}\right\rangle}\right\}^{2}+\left\{\frac{u\left(\delta K_{f B}\right)}{\left\langle K_{f B}\right\rangle}\right\}
\end{aligned}
$$

また, 同一の標準器で校正される流量計 $\mathrm{A}$ と流量計Bの校正に伴う補正值の間には相関関係があるとともに，そ れぞれの相対標準不確かさは同じ值 $\left(u\left(K_{f A C A L}\right) / K_{f A}=u\left(K_{f B C A L}\right) / K_{f B}\right)$ であることから, 式(20)の右辺第 $1 \sim 3$ 項 に対する校正に伴う補正值の寄与分は, $\overline{q_{X}}=\overline{q_{A}}-\overline{q_{B}}$ より式(23)で表される.

$$
\begin{aligned}
& {\left[\left\{\frac{\overline{q_{A}}}{\overline{q_{X}}}\right\}^{2}\left\{\frac{u\left(K_{f A}\right)}{K_{f A}}\right\}^{2}+\left\{\frac{\overline{q_{B}}}{\overline{q_{X}}}\right\}^{2}\left\{\frac{u\left(K_{f B}\right)}{K_{f B}}\right\}^{2}-2 \frac{\overline{q_{A}}}{\overline{q_{X}}} \frac{\overline{q_{B}}}{\overline{q_{X}}} r\left\{\frac{1}{K_{f A}}, \frac{1}{K_{f B}}\right\}\left\{\frac{u\left(K_{f A}\right)}{K_{f A}}\right\}\left\{\frac{u\left(K_{f B}\right)}{K_{f B}}\right\}\right]_{C A L}} \\
& =\left\{\frac{\overline{q_{A}}}{\overline{q_{X}}}\right\}^{2}\left\{\frac{u\left(K_{f A C A L}\right)}{\left\langle K_{f A}\right\rangle}\right\}^{2}+\left\{\frac{\overline{q_{B}}}{\overline{q_{X}}}\right\}^{2}\left\{\frac{u\left(K_{f B C A L}\right)}{\left\langle K_{f B}\right\rangle}\right\}^{2}-2 \frac{\overline{q_{A}}}{\overline{q_{X}}} \frac{\overline{q_{B}}}{\overline{q_{X}}}\left\{\frac{u\left(K_{f A C A L}\right)}{\left\langle K_{f A}\right\rangle}\right\}\left\{\frac{u\left(K_{f B C A L}\right)}{\left\langle K_{f B}\right\rangle}\right\}=\left\{\frac{u\left(K_{f A C A L}\right)}{\left\langle K_{f A}\right\rangle}\right\}^{2}
\end{aligned}
$$

したがって, 式(20)の右辺第 1〜3 項の流量計A及び流量計Bに起因する相対標準不確かさは, 式(21), (22), (23)よ り式(24)に展開される.

$$
\begin{aligned}
& \left\{\frac{\overline{q_{A}}}{\overline{q_{X}}}\right\}^{2}\left\{\frac{u\left(K_{f A}\right)}{K_{f A}}\right\}^{2}+\left\{\frac{\overline{q_{B}}}{\overline{q_{X}}}\right\}^{2}\left\{\frac{u\left(K_{f B}\right)}{K_{f B}}\right\}^{2}-2 \frac{\overline{q_{A}}}{\overline{q_{X}}} \frac{\overline{q_{B}}}{\bar{q}_{X}} r\left\{\frac{1}{K_{f A}}, \frac{1}{K_{f B}}\right\}\left\{\frac{u\left(K_{f A}\right)}{K_{f A}}\right\}\left\{\frac{u\left(K_{f B}\right)}{K_{f B}}\right\} \\
& =\left\{\frac{u\left(K_{f A C A L}\right)}{\left\langle K_{f A}\right\rangle}\right\}^{2}+\left\{\frac{\overline{q_{A}}}{\overline{q_{X}}}\right\}^{2}\left[\left(3 \alpha_{F M}\right)^{2} u^{2}\left(T_{A C A L}-T_{A}\right)+\left\{3\left(T_{A C A L}-T_{A}\right)\right\}^{2} u^{2}\left(\alpha_{F M}\right)\right. \\
& +\left\{\frac{u\left(\delta K_{f A, L N R}\right)}{\left\langle K_{f A}\right\rangle}\right\}^{2}+\left\{\frac{u\left(\delta K_{f A, R P R}\right)}{\left\langle K_{f A}\right\rangle}\right\}^{2}+\left\{\frac{u\left(\delta K_{f A, p}\right)}{\left\langle K_{f A}\right\rangle}\right\}^{2}+\left\{\frac{u\left(\delta K_{f A, v}\right)}{\left\langle K_{f A}\right\rangle}\right\}^{2}+\left\{\frac{u\left(\delta K_{f A}\right)}{\left\langle K_{f A}\right\rangle}\right\} \\
& +\left\{\frac{\overline{q_{B}}}{\bar{q}_{X}}\right\}^{2}\left[\left(3 \alpha_{F M}\right)^{2} u^{2}\left(T_{B C A L}-T_{B}\right)+\left\{3\left(T_{B C A L}-T_{B}\right)\right\}^{2} u^{2}\left(\alpha_{F M}\right)\right. \\
& \left.+\left\{\frac{u\left(\delta K_{f B, L N R}\right)}{\left\langle K_{f B}\right\rangle}\right\}^{2}+\left\{\frac{u\left(\delta K_{f B, R P R}\right)}{\left\langle K_{f B}\right\rangle}\right\}^{2}+\left\{\frac{u\left(\delta K_{f B, p}\right)}{\left\langle K_{f B}\right\rangle}\right\}^{2}+\left\{\frac{u\left(\delta K_{f B, v}\right)}{\left\langle K_{f B}\right\rangle}\right\}^{2}+\left\{\frac{u\left(\delta K_{f B}\right)}{\left\langle K_{f B}\right\rangle}\right\}\right]^{2}
\end{aligned}
$$

式(24)より流量計に起因する不確かさは減算流量比 $\left(\overline{q_{X}} / \overline{q_{A}}\right)$ によって増大寸ることがわかる. 次に，主に流 量計Bに起因寸る不確かさ解析について述べる.

\section{$4 \cdot 3 \cdot 1$ 流量計校正に伴う補正值に起因する不確かさ}

前述のとおり, 流量計A及び流量計Bは同時に校正されることから, 流量計校正に伴う補正值に起因する標淮不 確かさ $u\left(K_{f A C A L}\right)$ は, 流量計の偶然効果による寄与を除いた校正設備による体積流量計の校正の相対標準不確か さと見なすことができ，式(25)で表される(5). 


$$
\frac{u\left(K_{\text {fACAL }}\right)}{\left\langle K_{f A}\right\rangle}=1.5 \times 10^{-4}
$$

\section{$4 \cdot 3 \cdot 2$ 流量計の熱膨張係数及び温度測定に起因する不確かさ}

流量計の流量計本体材質の線膨張係数 $\alpha_{F M}\left(=1.1 \times 10^{-5} \mathrm{~K}^{-1}\right)$ の誤差を $10 \%$ と仮定した場合, 流量計 B を校正した 際の流量計の温度と減算法による校正時の温度の差が $0.15 \mathrm{~K}$ 以下であることから，20 ${ }^{\circ} \mathrm{C}$ 基準の流量計の相対 $\mathrm{K}$ 值に及ぼす流量計の線膨張係数の不確かさによる寄与は $5 \times 10^{-7}$ 以下であると推定された. また, 流量計 B を校正 した際の流量計の温度と減算法による校正時の温度の差の不確かさは，同一の温度計で測定されていること，ま た校正時の温度環境と液体温度の差が小さいことから，主に温度計の再現性に起因すると考えられ，本報では温 度差による標準不確かさを $0.02 \mathrm{~K}$ 以下であると見積もる.したがって, 相対 $\mathrm{K}$ 值に及ぼす流量計の温度補正によ る寄与は， $6.6 \times 10^{-7}$ であると推定される.

\section{$4 \cdot 3 \cdot 3$ 流量計の直線性, 圧力, 試験液物性に起因する不確かさ}

減算法における流量計B $\mathrm{B}$ K值 $K_{f B}$ に寄与寸る流量計Bの直線性に伴う不確かさは, パルス周波数に対するK值 の感度係数とパルス周波数の不確かさの積で表され，また，パルス取得に伴う不確かさを零と見なすことから， パルス周波数の測定に伴う不確かさは時間計測の不確かさで表される. したがって，パルス周波数に対する相対 K值の感度係数は式(16)より $9.6 \times 10^{-7}$ であり, 時間計測の相対標準不確かさが $1 \times 10^{-5}$ であることから, 流量計B $の$ 直線性に起因する相対標準不確かさは式(26)で表される.

$$
\frac{u\left(\delta K_{f B, L N R}\right)}{\left\langle K_{f B}\right\rangle} \approx\left|\frac{\partial\left(K_{f 20, f i t} /\left\langle K_{f B}\right\rangle\right)}{\partial f_{P}}\right| u\left(f_{P}\right) \approx\left|\frac{\partial\left(K_{f 20, f i t} /\left\langle K_{f B}\right\rangle\right)}{\partial f_{P}}\right|\left|f_{P}\right| \frac{u\left(t_{P}\right)}{t_{P}}=9.6 \times 10^{-7} \times 730 \times 1 \times 10^{-5}=7.0 \times 10^{-9}
$$

相対 $\mathrm{K}$ 值に及ぼす測定圧力の影響は，圧力を変えた校正を行った結果， $5 \times 10^{-5}\left(\mathrm{MPa}^{-1}\right)$ 以下であった．測定時 における誤差が $\pm 0.01 \mathrm{MPa}$ 以下であることから, 相対 K 值に及ぼす測定圧力の寄与 $u\left(\delta K_{f B, p}\right) /\left\langle K_{f B}\right\rangle$ は $5 \times 10^{-7}$ 以

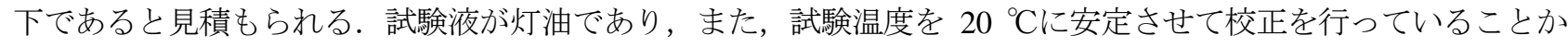
ら, 校正の違いによって生じる動粘度, 密度の偏差は小さい. したがって, 試験液物性の影響は流量計の再現性 による寄与に含まれると考えられる。

\section{$4 \cdot 3 \cdot 4$ 流量計の再現性及び繰り返し性に起因する不確かさ}

同一日に繰り返し測定を行った結果, 流量計BのK值の平均の相対標準偏差は最大で $0.0006 \%$ あった. また,

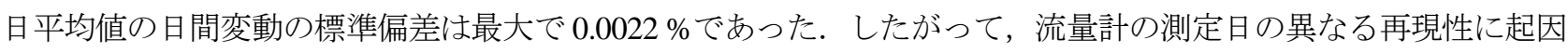
する相対標準不確かさ及び流量計の偶然効果に起因する相対標準不確かさはそれぞれ式(27), (28)から見積もられ る.

$$
\begin{aligned}
& \frac{u\left(\delta K_{f B, R P R}\right)}{\left\langle K_{f B}\right\rangle}=2.2 \times 10^{-5} \\
& \frac{u\left(\delta K_{f B}\right)}{\left\langle K_{f B}\right\rangle}=6 \times 10^{-6}
\end{aligned}
$$

式(24)より見積もられた流量計A及び流量計Bに起因する相対標準不確かさをまとめたものを表 3 に示す. 今回 実施した校正では, 流量計A及び流量計Bに起因寸る不確かさは, 流量計の再現性及び偶然効果に支配されること がわかる. 
Table 3 Uncertainty due to flowmeter A and B

\begin{tabular}{|c|c|c|c|c|c|c|}
\hline & \multirow[b]{2}{*}{ Source } & \multirow[b]{2}{*}{ Section } & \multirow{2}{*}{$\begin{array}{c}\text { Relative } \\
\text { standard } \\
\text { uncertainty }\end{array}$} & \multicolumn{3}{|c|}{ Relative standard uncertainty } \\
\hline & & & & $\begin{array}{c}\overline{q_{X}} / \overline{q_{A}}= \\
0.08\end{array}$ & $\begin{array}{c}\overline{q_{X}} / \overline{q_{A}}= \\
0.02\end{array}$ & $\begin{array}{c}\overline{q_{X}} / \overline{q_{A}}= \\
0.01\end{array}$ \\
\hline \multicolumn{2}{|c|}{ Calibration of flowmeters } & $4 \cdot 3 \cdot 1$ & $1.5 \times 10^{-4}$ & $1.5 \times 10^{-4}$ & $1.5 \times 10^{-4}$ & $1.5 \times 10^{-4}$ \\
\hline \multirow{6}{*}{$\begin{array}{l}\text { Flowmeter } \\
\text { A }\end{array}$} & Thermal coefficient & $4 \cdot 3 \cdot 2$ & $5.0 \times 10^{-7}$ & $6.4 \times 10^{-6}$ & $2.5 \times 10^{-5}$ & $4.9 \times 10^{-5}$ \\
\hline & Temperature & $4 \cdot 3 \cdot 2$ & $6.6 \times 10^{-7}$ & $8.1 \times 10^{-6}$ & $3.3 \times 10^{-5}$ & $6.6 \times 10^{-5}$ \\
\hline & Linearity & $4 \cdot 3 \cdot 3$ & $8.1 \times 10^{-9}$ & $1.0 \times 10^{-7}$ & $4.0 \times 10^{-7}$ & $8.0 \times 10^{-7}$ \\
\hline & Pressure & $4 \cdot 3 \cdot 3$ & $5.0 \times 10^{-7}$ & $6.5 \times 10^{-6}$ & $2.5 \times 10^{-6}$ & $5.0 \times 10^{-6}$ \\
\hline & Reproducibility & $4 \cdot 3 \cdot 4$ & $1.6 \times 10^{-5}$ & $2.1 \times 10^{-4}$ & $8.0 \times 10^{-4}$ & $1.6 \times 10^{-3}$ \\
\hline & Random & $4 \cdot 3 \cdot 4$ & $8.0 \times 10^{-6}$ & $1.0 \times 10^{-4}$ & $4.0 \times 10^{-4}$ & $8.0 \times 10^{-4}$ \\
\hline \multirow{6}{*}{$\begin{array}{l}\text { Flowmeter } \\
\text { B }\end{array}$} & Thermal coefficient & $4 \cdot 3 \cdot 2$ & $5.0 \times 10^{-7}$ & $5.9 \times 10^{-6}$ & $2.4 \times 10^{-5}$ & $4.9 \times 10^{-5}$ \\
\hline & Temperature & $4 \cdot 3 \cdot 2$ & $6.6 \times 10^{-7}$ & $7.9 \times 10^{-6}$ & $3.2 \times 10^{-5}$ & $6.5 \times 10^{-5}$ \\
\hline & Linearity & $4 \cdot 3 \cdot 3$ & $7.0 \times 10^{-9}$ & $8.4 \times 10^{-8}$ & $3.4 \times 10^{-7}$ & $6.9 \times 10^{-7}$ \\
\hline & Pressure & $4 \cdot 3 \cdot 3$ & $5.0 \times 10^{-7}$ & $6.0 \times 10^{-6}$ & $2.4 \times 10^{-5}$ & $4.9 \times 10^{-5}$ \\
\hline & Reproducibility & $4 \cdot 3 \cdot 4$ & $2.2 \times 10^{-5}$ & $2.6 \times 10^{-4}$ & $1.1 \times 10^{-3}$ & $2.2 \times 10^{-3}$ \\
\hline & Random & $4 \cdot 3 \cdot 4$ & $6.0 \times 10^{-6}$ & $7.2 \times 10^{-5}$ & $2.9 \times 10^{-4}$ & $5.9 \times 10^{-4}$ \\
\hline \multicolumn{4}{|c|}{ Relative combined standard uncertainty } & $3.9 \times 10^{-4}$ & $1.4 \times 10^{-3}$ & $2.9 \times 10^{-3}$ \\
\hline
\end{tabular}

\section{$4 \cdot 4$ 密度測定の不確かさ}

流量計A，流量計B及び流量計Xを通過する密度測定に起因する標準不確かさは式(11), (12)より式(29)に展開さ れる.

$$
\begin{aligned}
u^{2}\left(\frac{\overline{q_{A}}}{\overline{q_{X}}} \frac{\overline{\rho_{A}}}{\overline{\rho_{X}}}-\frac{\overline{q_{B}}}{\overline{q_{X}}} \frac{\overline{\rho_{B}}}{\overline{\rho_{X}}}\right) & =\left\{\frac{\alpha_{L}}{\rho_{R E F}}\left(\frac{\overline{q_{A}}}{\overline{q_{X}}} T_{A}-\frac{\overline{q_{B}}}{\overline{q_{X}}} T_{B}-T_{X}\right)\right\}^{2}\left\{\frac{u\left(\rho_{\text {REF }}\right)}{\rho_{R E F}}\right\}^{2}+\left(\frac{\overline{q_{A}}}{\overline{q_{X}}} T_{A}-\frac{\overline{q_{B}}}{\overline{\overline{q_{X}}}} T_{B}-T_{X}\right)^{2}\left\{\frac{u\left(\alpha_{L}\right)}{\rho_{R E F}}\right\}^{2} \\
& +\left(\frac{\alpha_{L}}{\rho_{R E F}}\right)^{2} u^{2}\left(\frac{\overline{q_{A}}}{\overline{q_{X}}} T_{A}-\frac{\overline{q_{B}}}{\overline{q_{X}}} T_{B}-T_{X}\right) \\
& +\left(\frac{\overline{q_{A}}}{\overline{q_{X}}} p_{A}-\frac{\overline{q_{B}}}{\overline{q_{X}}} p_{B}-p_{X}\right)^{2} u^{2}\left(\beta_{L}\right)+\beta_{L}^{2} \cdot u^{2}\left(\frac{\overline{q_{A}}}{\overline{q_{X}}} p_{A}-\frac{\overline{q_{B}}}{\overline{q_{X}}} p_{B}-p_{X}\right)
\end{aligned}
$$

さらに, $\overline{q_{A}}, \overline{q_{B}} \gg \overline{q_{X}}$ であり, また流量計 $\mathrm{A}$, 流量計 $\mathrm{B}$, 流量計 $\mathrm{X} 1$ 及びX2 での温度測定及び圧力測定の不確か さが同程度であると推測されることから, 密度測定に起因する標準不確かさは式(29)より式(30)で求められる.

$$
u^{2}\left(\frac{\overline{q_{A}}}{\overline{\overline{q_{X}}}} \frac{\overline{\rho_{A}}}{\overline{\rho_{X}}}-\frac{\overline{q_{B}}}{\overline{\overline{q_{X}}}} \frac{\overline{\rho_{B}}}{\overline{\rho_{X}}}\right)=\left\{\begin{array}{l}
\overline{\overline{q_{A}}} \\
\overline{\overline{q_{X}}}
\end{array}\right\}^{2}\left[\begin{array}{l}
\left\{\frac{\alpha_{L}\left(T_{A}-T_{B}\right)}{\rho_{R E F}{ }^{2}}\right\}^{2} u^{2}\left(\rho_{R E F}\right)+\left(\frac{T_{A}-T_{B}}{\rho_{R E F}}\right)^{2} u^{2}\left(\alpha_{L}\right) \\
+\left(\frac{\alpha_{L}}{\rho_{R E F}}\right)^{2} u^{2}\left(T_{A}-T_{B}\right)+\left(p_{A}-p_{B}\right)^{2} u^{2}\left(\beta_{L}\right)+\beta_{L}^{2} \cdot u^{2}\left(p_{A}-p_{B}\right)
\end{array}\right]
$$

\section{4・4・1 密度計による密度測定の不確かさ}

振動式密度計は乾燥空気と校正值の不確かさが $0.03 \mathrm{~kg} / \mathrm{m}^{3}$ (包含係数 $k=2$ ) である密度標準液(水)で調整され る. 密度計による試験液密度の測定值の標淮不確かさ $u\left(\rho_{R E F}\right)$ は密度標準液の不確かさである $0.015 \mathrm{~kg} / \mathrm{m}^{3}$ に相当 
すると推定された。 流量計Aと流量計Bの温度差 $\left(T_{A}-T_{B}\right)$ が $0.06 \mathrm{~K}$ 以下であったことから， $\alpha_{L}$ が- $0.731 \mathrm{~kg} /\left(\mathrm{m}^{3} \mathrm{~K}\right)$, $\rho_{R E F}$ が $795 \mathrm{~kg} / \mathrm{m}^{3}$ であることより試験液密度に対する密度計による密度測定の寄与は式(31)で推定された.

$$
\left|\frac{\alpha_{L}\left(T_{A}-T_{B}\right)}{\rho_{R E F}^{2}}\right| u\left(\rho_{R E F}\right)=\left|\frac{-0.731 \times 0.06}{795^{2}}\right| \times 0.015=1.4 \times 10^{-9}
$$

\section{$4 \cdot 4 \cdot 2$ 試験液の熱膨張係数の不確かさ}

試験液の温度に対する密度の感度係数（熱膨張係数） $\alpha_{L}$ は温度 $15{ }^{\circ} \mathrm{C}$ で測定された密度と $35{ }^{\circ} \mathrm{C}$ での測定值か ら得られ, 熱膨張係数の標準不確かさは $0.0033 \mathrm{~kg} /\left(\mathrm{m}^{3} \mathrm{~K}\right)$ と見積もられた。したがって, 試験液密度に対する試験 液の熱膨張係数の寄与は式(32)で見積もられた.

$$
\left|\frac{T_{A}-T_{B}}{\rho_{R E F}}\right| u\left(\alpha_{L}\right)=\left|\frac{0.06}{795}\right| \times 0.0033=2.5 \times 10^{-7}
$$

\section{$4 \cdot 4 \cdot 3$ 温度測定の不確かさ}

流量計 $\mathrm{A}$ の試験液温度 $T_{A}$ は, 流量計の下流部に設置された温度計の指示值 $T_{A m}$ から推定され, 温度計は温槽を 介して標準温度計により校正されることから，不確かさ解析のためのモデル式は式(33)で表される.

$$
T_{A}=T_{A m}+\delta T_{A, S T}+\delta T_{A, B A T H}+\delta T_{A, T H M}+\delta T_{A}
$$

ここで, $\delta T_{A, S T}\left({ }^{\circ} \mathrm{C}\right), \delta T_{A, B A T H}\left({ }^{\circ} \mathrm{C}\right), \delta T_{A, T H M}\left({ }^{\circ} \mathrm{C}\right), \delta T_{A}\left({ }^{\circ} \mathrm{C}\right)$ はそれぞれ, 標準温度計からの補正值, 温槽に起 因する温度補正值，温度計に起因する温度補正値，温度計設置位置と流量計内との試験液温度差を意味する. 温 度計の最小目盛りが 0.001 Kであることから丸め誤差による影響は無視した. 同一の標準温度計で温度計は校正さ れることから, 温度測定值 $T_{A}$ 及び $T_{B}$ の標準温度計による補正值の間に相関関係があると考えられる. また, 本研 究では, 10 t秤量システムによる流量計Aの校正時と流量減算時に同一の温度計を用いて温度測定を行ったことか ら, 流量計Aの校正時における温槽に起因する温度補正值と流量減算時の温度補正值との間に相関関係があると 考えられる. したがって, 温度測定の標準不確かさは式(34)で表される.

$$
u^{2}\left(T_{A}-T_{B}\right)=u^{2}\left(T_{A m}\right)+u^{2}\left(\delta T_{A, \text { TнM }}\right)+u^{2}\left(\delta T_{A}\right)+u^{2}\left(T_{B m}\right)+u^{2}\left(\delta T_{B, T H M}\right)+u^{2}\left(\delta T_{B}\right)
$$

温度計の指示值による標準不確かさは平均の実験標準不確かさであることから，0.001 K以下であると見積もら れた. また, 再現性が主な要因である温度計に起因寸る標準不確かさは $0.017 \mathrm{~K}$ なることが確認された.さらに, 流量計の上流部と下流部において測定した值からその最大温度差は 0.03 Kであることが確認された．流量計下流 部の温度計設置位置と流量計内との試験液温度差は, この温度差が管路に対して一様に分布すると仮定すると, 標準不確かさ $u\left(\delta T_{A}\right), u\left(\delta T_{B}\right)$ は $0.009 \mathrm{~K}$ 推定された。したがって, 式(34)より温度測定の標準不確かさ $u\left(T_{A}-T_{B}\right)$ は $0.027 \mathrm{~K}$ 得た。試験液密度に対する試験液の熱膨張係数の寄与は $2.5 \times 10^{-5}$ であると見積もられた.

\section{$4 \cdot 4 \cdot 4$ 試験液の圧縮率による不確かさ}

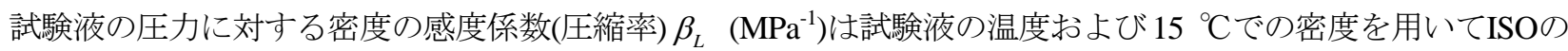
推算式 ${ }^{(8)}$ より求められる. この推算式の拡張不確かさ $(k=2)$ は $6.5 \%$ \%市るとが記述されていることから, 圧縮 率の相対標準不確かさ $u\left(\beta_{L}\right) / \beta_{L}$ として $3.3 \times 10^{-2}$ を得た. 流量計 $\mathrm{A}$ と流量計B $の$ 圧力差は $0.15 \mathrm{MPa}$ 以下であること から，試験液密度に対する相対標準不確かさの寄与は $4.4 \times 10^{-6}$ であると見積もられた.

\section{$4 \cdot 4 \cdot 5$ 圧力測定の不確かさ}

流量計A内の試験液の圧力 $p_{A}(\mathrm{MPa})$ は, 流量計上流に設置された圧力計(ゲージ圧計)による測定值 $p_{A m U}(\mathrm{MPa})$ 及び下流での測定值 $p_{A m D}$ を平均した值から推定され, 不確かさ解析のためのモデル式は式(35)で表される. 


$$
p_{A}=\frac{p_{A m U}+\delta p_{A C U}+p_{A m D}+\delta p_{A C D}}{2}+\delta p_{A}
$$

ここで, $\delta p_{A C U}(\mathrm{MPa}), \delta p_{A C D}(\mathrm{MPa})$ は流量計上流部または下流部に設置された圧力計の補正值であり, $\delta p_{A}$ は 流量計上流及び下流部での平均值と流量計内での圧力との差を意味する. また, 圧力計の最小目盛りが $0.001 \mathrm{MPa}$ であることから，丸め誤差による影響は無視した．流量計B内の試験液の圧力 $p_{B}(\mathrm{MPa})$ も式(35) と同様の式で表 され，使用される圧力計は同一の標準圧力計で比較校正されることから，校正值の相関係数を 1 として取り扱っ た．また，上流及び下流に設置されている圧力計はほぼ同じ性能を有することから，流量計A内圧力と流量計B の圧力との差の標準不確かさ $u\left(p_{A}-p_{B}\right)$ は式(36)で表される.

$$
u^{2}\left(p_{A}-p_{B}\right)=\frac{u^{2}\left(p_{A m U}\right)+u^{2}\left(p_{A m D}\right)+u^{2}\left(p_{B m U}\right)+u^{2}\left(p_{B m D}\right)}{2}+u^{2}\left(\delta p_{A}\right)+u^{2}\left(\delta p_{A}\right)
$$

まず，圧力計の指示值として校正中に計測された圧力の時間平均值を用いることから，圧力計の指示值による 標準不確かさ $u\left(p_{A m}\right)$ として平均の実験標準偏差 0.001 MPaを採用した. さらに，10 t科量システムによる校正時 に設置された流量計A及びBを用いて流量減算を行うこと, また流量, 動粘度が一定である場合には流量計等で生 じる圧力損失はほぼ一定であるであることから，10 t科量システムよる校正時における流量計上流及び下流部で の平均値と流量計内での圧力との差と流量減算時の圧力差との間には相関関係があると考えられる. したがって, 測定平均值と流量計内圧力との差による標準不確かさ $u\left(\delta p_{A}\right), u\left(\delta p_{A}\right)$ は, 圧力差の標淮偏差である $0.003 \mathrm{MPa}$ であると見積もられた，以上の不確かさを式(36)に適用すると， $u\left(p_{A}-p_{B}\right)$ は $0.004 \mathrm{MPa}$ であり，また，密度に対 する相対標準不確かさは $4.0 \times 10^{-6}$ であると推定された.

\section{$4 \cdot 4 \cdot 6$ 密度測定の不確かさのまとめ}

前述の密度測定に及ぼす各要因の標準不確かさと式(30)より, 流量計内の試験液密度の相対標準不確かさが求 まる．相対標準不確かさをまとめたものを表 4 に示す，密度測定に起因する不確かさは，流量計内の温度測定に 支配されることがわかる.

\begin{tabular}{|c|c|c|c|c|c|}
\hline \multirow[b]{2}{*}{ Source } & \multirow[b]{2}{*}{ Section } & \multirow{2}{*}{$\begin{array}{c}\text { Relative } \\
\text { standard } \\
\text { uncertainty }\end{array}$} & \multicolumn{3}{|c|}{ Relative standard uncertainty } \\
\hline & & & $\overline{q_{X}} / \overline{q_{A}}=0.08$ & $\overline{q_{X}} / \overline{q_{A}}=0.02$ & $\overline{q_{X}} / \overline{q_{A}}=0.01$ \\
\hline Density meter & $4 \cdot 4 \cdot 1$ & $1.4 \times 10^{-9}$ & $1.8 \times 10^{-8}$ & $6.9 \times 10^{-8}$ & $1.4 \times 10^{-7}$ \\
\hline Thermal coefficient & $4 \cdot 4 \cdot 2$ & $2.5 \times 10^{-7}$ & $3.2 \times 10^{-6}$ & $1.2 \times 10^{-5}$ & $2.5 \times 10^{-5}$ \\
\hline Temperature & $4 \cdot 4 \cdot 3$ & $2.5 \times 10^{-5}$ & $3.3 \times 10^{-4}$ & $1.2 \times 10^{-3}$ & $2.5 \times 10^{-3}$ \\
\hline Compressibility & $4 \cdot 4 \cdot 4$ & $4.4 \times 10^{-6}$ & $5.7 \times 10^{-5}$ & $2.2 \times 10^{-4}$ & $4.4 \times 10^{-4}$ \\
\hline Pressure & $4 \cdot 4 \cdot 5$ & $4.0 \times 10^{-6}$ & $5.1 \times 10^{-5}$ & $2.0 \times 10^{-4}$ & $4.0 \times 10^{-4}$ \\
\hline \multicolumn{3}{|c|}{ Relative combined standard uncertainty } & $3.3 \times 10^{-4}$ & $1.3 \times 10^{-3}$ & $2.6 \times 10^{-3}$ \\
\hline
\end{tabular}

Table 4 Relative uncertainty due to density measurement

\section{$4 \cdot 5$ 時間計測の不確かさ}

パルス計数時間の不確かさ解析のためのモデル式は式(37)で推定される.

$$
t_{P}=t_{P m}+t_{P C}+\delta t_{P}
$$

ここで， $t_{P m}(\mathrm{~s}), t_{P C}(\mathrm{~s}), \delta t_{P}(\mathrm{~s})$ はそれぞれパルス計時器の指示時間, 補正時間, 再現性を意味する. パルス 計時器の指示時間の標準不確かさはパルス計時器の分解能に相当する. パルス計時器はパルス計時器内蔵の水晶 発振器から発信される時間パルス数を積算することにより時間を計測する. 流量計 $\mathrm{A}, \mathrm{B}, \mathrm{X} 1, \mathrm{X} 2$ のパルス計時器 内で同一の水晶発振器が使用されている場合, 時間パルス積算数の不確かさを無視することができるので, それ 
ぞれの計時器の間には補正時間による不確かさ及び再現性による不確かさに相関関係があると考えられる.した がって，式(20)の右辺第 5 項の時間計測に伴う不確かさは式(38)で表される.

$$
u^{2}\left(\frac{\overline{q_{A}}}{\overline{\overline{q_{X}}}} \frac{t_{p X}}{t_{p A}}-\frac{\overline{q_{B}}}{\overline{\overline{q_{X}}}} \frac{t_{p X}}{t_{p B}}\right)=\left\{\frac{\overline{q_{A}}}{\overline{q_{X}}}\right\}^{2}\left\{\frac{u\left(t_{p A m}\right)}{t_{p A}}\right\}^{2}+\left\{\frac{\overline{q_{B}}}{\overline{\overline{q_{X}}}}\right\}^{2}\left\{\frac{u\left(t_{p B m}\right)}{t_{p B}}\right\}^{2}+\left\{\frac{u\left(t_{p X m}\right)}{t_{p X}}\right\}^{2}
$$

パルス計時器の指示時間の標準不確かさはパルス計時器の分解能 $\left(1.0 \times 10^{-6} \mathrm{~s}\right)$ に相当し, 計測時間 $t_{p A}$ は約 $140 \mathrm{~s}$ であるとから, 時間計測の相対標準不確かさ $u\left(t_{p A m}\right) / t_{p A}, u\left(t_{p B m}\right) / t_{p B}, u\left(t_{p X m}\right) / t_{p X}$ は $2.1 \times 10^{-9}$ であると推 定された. さらに, 流量計Xの流量が $23 \mathrm{~m}^{3} / \mathrm{h}$ である場合 $\left(\overline{q_{X}} / \overline{q_{A}}=0.08\right)$ には, 時間計測に起因する相対標準不 確かさは式(38)より $3.6 \times 10^{-8}$ であると見積もられた.

\section{$4 \cdot 6$ 接続管路内の質量変化}

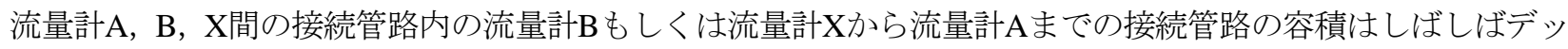
ドボリュームと呼ばれる．この管路内では流れ方向の各位置で試験液と管路の温度がほぼ等しいと仮定し，また 管路の熱膨張は試験液の熱膨張に対して非常に小さく無視できることから，接続管路内で校正時間に生じる質量 変化量 $\Delta M_{L D V}$ は式(39)で表される.

$$
\Delta M_{L D V}=\rho_{D V} V_{D V}\left\{\frac{\alpha_{L} \Delta T_{D V}}{\rho_{D V}}+\beta_{L} \Delta p_{D V}\right\}
$$

ここで, $\Delta p_{D V}(\mathrm{MPa}), \Delta T_{D V}(\mathrm{~K}), \alpha_{L} \mathrm{~kg} /\left(\mathrm{m}^{3} \mathrm{~K}\right), \beta_{L}\left(\mathrm{MPa}^{-1}\right), V_{D V}\left(\mathrm{~m}^{3}\right)$ はそれぞれ，計測開始から終了までに 生じる接続管路内の圧力変化量および温度変化量, 温度に対する密度の感度係数である熱膨張係数, 圧力に対す る密度の感度係数である圧縮率, 接続管路の体積である. $\Delta M_{L D V}$ の期待值を零と見なすことにより, 接続管路内 の質量の変化量による標準不確かさは式(40)に展開される.

$$
u^{2}\left(\Delta M_{L D V}\right)=\left(\alpha_{L} V_{D V}\right)^{2} u^{2}\left(\Delta T_{D V}\right)+\left(\rho_{D V} V_{D V} \beta_{L}\right)^{2} u^{2}\left(\Delta p_{D V}\right)
$$

ここで， $V_{D V}$ は $0.5 \mathrm{~m}^{3}$ 以下であり，また， $\rho_{D V}$ は $795 \mathrm{~kg} / \mathrm{m}^{3}$, 熱膨張係数 $\alpha_{L}$ は- $0.731 \mathrm{~kg} /\left(\mathrm{m}^{3} \mathrm{~K}\right)$, 圧縮率 $\beta_{L}$ は $8.9 \times 10^{-5} \mathrm{MPa}^{-1}$ であった. また, 測定前後での $\Delta T_{D V}$ は土 $0.02 \mathrm{~K}$ 以下, $\Delta p_{D V}$ は $\pm 0.002 \mathrm{MPa}$ 以下であった. これ ら誤差要因が一様分布に従うと想定すると, 温度変化による標準不確かさ $u\left(\Delta T_{D V}\right)$ は $0.011 \mathrm{~K}$, 圧力変化による 標準不確かさ $u\left(\Delta p_{D V}\right)$ は $0.0011 \mathrm{MPa}$ であると推定された。したがって，接続管路内にある試験液の質量変化に よる標準不確かさ $u\left(\Delta M_{L D V}\right)$ は $4.2 \times 10^{-3} \mathrm{~kg}$ であり，流量計 A を通過する質量に対する相対標準不確かさは $4.6 \times 10^{-7}$ であると推定された. さらに, 流量計 $\mathrm{X}$ の流量が $23 \mathrm{~m}^{3} / \mathrm{h}$ である場合 $\left(\overline{q_{X}} / \overline{q_{A}}=0.08\right)$ では, 接続管路 内にある試験液の質量変化による相対標準不確かさは $6.0 \times 10^{-6}$ であると見積もられた.

\section{$4 \cdot 7$ 流量計内での流量及び密度変動の影響}

流量計B内での密度変動と流量変動との相関に伴う影響分 $\Delta\left(\rho_{A} q_{A}\right)$ は, 密度変動強度 $\rho_{\text {Arms }}\left(\mathrm{kg} / \mathrm{m}^{3}\right)$ と流量変動 強度 $q_{\text {Arms }}\left(\mathrm{m}^{3} / \mathrm{s}\right)$ で表される式(41)で推定した.

$$
\Delta\left(\rho_{A} q_{A}\right) \leq \rho_{\text {Arms }} q_{\text {Arms }}
$$

$\rho_{\text {Arms }}$ は, 圧力変動, 温度変動及び試験液密度の再現性から $1 \times 10^{-3} \overline{\rho_{A}}$ 以下であると見積もられた.また, $q_{\text {Arms }}$ は $0.002 \overline{q_{A}}$ 以下であることから, 流量計内での密度変動と流量変動の影響による流量計を通過する体積に対する 相対標準不確かさは $2 \times 10^{-6}$ 以下であると評価された. 流量計 $\mathrm{A}$, 流量計 X1 及び X2 も同様に評価され, 流量計 $\mathrm{X}$ の流量が $23 \mathrm{~m}^{3} / \mathrm{h}$ である場合 $\left(\overline{q_{X}} / \overline{q_{A}}=0.08\right)$ には, 相関に伴う影響による相対標準不確かさは $3.5 \times 10^{-5}$ であ ると見積もられた。 


\section{$4 \cdot 8$ 流量計の偶然効果}

$1 \mathrm{t}$ 秤量システムを用いて流量計 $\mathrm{X} 1$ 及び流量計 X2 を単独で校正した場合の校正值の平均の実験標準偏差は 0.002 \%以下であるが，減算法で流量計 X1 及び X2 の流量が $3 \mathrm{~m} 3 / \mathrm{h}$ である場合には，校正值の平均の実験標準偏 差は約 $0.05 \%$ となる結果を得た。これは，減算法による流量計 X1 及び X2 の校正值の分散には，流量計 A 及び $\mathrm{B}$ 等の他の要因に起因寸るばらつき成分が含まれると考えられる.したがって, 流量計 X1 及び X2 の偶然効果に よる不確かさを個別に評価することは難しいが, 得られた減算法による校正值の分散には流量計 X1 及び X2 以外 の要因の偶然効果も含まれた值と見なし, 偶然効果に起因する標準不確かさは平均の実験標準偏差で推定され, 表 5 に示寸結果を得た.

Table 5 Relative standard uncertainty due to random effect

\begin{tabular}{|l|l|l|l|}
\hline \multirow{2}{*}{ Source } & \multicolumn{3}{|c|}{ Relative standard uncertainty } \\
\cline { 2 - 4 } & \multicolumn{1}{|c|}{$\overline{q_{X}} / \overline{q_{A}}=0.08$} & $\overline{q_{X}} / \overline{q_{A}}=0.02$ & $\overline{q_{X}} / \overline{q_{A}}=0.01$ \\
\hline Flowmeter X1 & $<9.8 \times 10^{-5}$ & $<3.1 \times 10^{-4}$ & $<4.8 \times 10^{-4}$ \\
\hline Flowmeter X2 & $<9.2 \times 10^{-5}$ & $<3.0 \times 10^{-4}$ & $<4.7 \times 10^{-4}$ \\
\hline
\end{tabular}

Table 6 Relative standard uncertainty of calibration for flowmeter X1 and X2

\begin{tabular}{|l|c|c|c|c|}
\hline \multirow{2}{*}{ Source } & \multirow{2}{*}{ Section } & \multicolumn{3}{c|}{ Relative standard uncertainty } \\
\cline { 3 - 5 } & & $\overline{q_{X}} / \overline{q_{A}}=0.08$ & $\overline{q_{X}} / \overline{q_{A}}=0.02$ & $\overline{q_{X}} / \overline{q_{A}}=0.01$ \\
\hline Flowmeter & $4 \cdot 3$ & $3.9 \times 10^{-4}$ & $1.4 \times 10^{-3}$ & $2.9 \times 10^{-3}$ \\
\hline Density & $4 \cdot 4$ & $3.3 \times 10^{-4}$ & $1.3 \times 10^{-3}$ & $2.6 \times 10^{-3}$ \\
\hline Time & $4 \cdot 5$ & $3.6 \times 10^{-8}$ & $1.4 \times 10^{-7}$ & $2.9 \times 10^{-7}$ \\
\hline Mass in connection pipe & $4 \cdot 6$ & $6.0 \times 10^{-6}$ & $2.3 \times 10^{-5}$ & $4.6 \times 10^{-5}$ \\
\hline Correlation & $4 \cdot 7$ & $3.5 \times 10^{-5}$ & $1.4 \times 10^{-4}$ & $2.8 \times 10^{-4}$ \\
\hline Random & $4 \cdot 8$ & $<9.8 \times 10^{-5}$ & $<3.1 \times 10^{-4}$ & $<4.8 \times 10^{-4}$ \\
\hline Relative combined standard uncertainty & $5.3 \times 10^{-4}$ & $2.0 \times 10^{-3}$ & $4.0 \times 10^{-3}$ \\
\hline Expanded uncertainty $(k=2)$ & & $0.11 \%$ & $0.40 \%$ & $0.79 \%$ \\
\hline
\end{tabular}

\section{$4 \cdot 9$ 不確かさのまとめ}

前節までに求めた各要因の相対標準不確かさを式(20)に代入すると, 流量計Xの偶然効果を除いた校正の不確か さが求まる. 不確かさ要因の相対標準不確かさと相対合成標準不確かさをまとめたものを表 6 に示す. 以上の解 析により, 減算法による校正の不確かさは流量計の再現性と流量計内の温度測定に起因する不確かさに支配され ることがわかる. また，相対拡張不確かさの包含係数 $k$ を 2 として求めた場合には，K 值の測定結果に付随する 相対拡張不確かさは，表 6 に示寸 $0.11 \% \sim 0.79 \%$ と見積もられる. 減算法で得られたK值は不確かさの範囲内 で科量システムにより得られた值と一致することから，見積もられた不確かさが妥当であることがわかる.

また, 減算法の不確かさの算出式からわかるように, 不確かさ要因の多くは流量比 $\left(\overline{q_{X}} / \overline{q_{A}}\right)$ に反比例して増 大寸る．このことは，同時に校正された流量計同士の校正值には相関関係があることから，1 回の減算によって 一度に小さな標淮流量で流量計を校正する方法よりも, 複数回の減算法による方法で評価される不確かさが小さ くなることを示唆する，さらに，質量流量計を使用した場合には，密度測定に起因する不確かさを考慮する必要 がないため, 体積流量計による校正に比べ，精度良く校正できる可能性があると言える. 


\section{5. 考察}

前章の不確かさ解析により, 減算法による校正の不確かさは流量計の再現性と流量計内の温度測定に支配され ることがわかった。 そこで，流量計A及び流量計Bの再現性による寄与を除去するために，減算法による流量計 $\mathrm{X} 1$ 及びX2 の校正と同じ日に得た流量計A及び流量計BのK值を用いて流量計X1 及び流量計X2 のK值を算出した. $1 \mathrm{t}$ 秤量システムを用いて得たK值に対する相対偏差を図 6 に，またYouden プロットを図 7 に示す. 図 6 よりK值 の相対偏差は $\pm 0.2 \%$ 以下であり，流量計 $\mathrm{A}$ と流量計Bの近似曲線式を使用したK值の相対偏差（図 4）に比へ，同 一日のK值を使用した相対偏差は小さくなったことがわかる．このことは，同一日に得た校正值を使用すること により流量計A及びBの再現性による寄与を小さくすることができることを示す. しかしながら, Fig. 7 より 2 種 類の流量計の校正值には強い正の相関があることから, 流量計X1 及びX2 の偏差は主に減算法によって算出され る標準流量の偏差によって生じることがわかる.

また, 流量計 A, B の再現性及び温度計の再現性に起因する不確かさを除いた場合には, 校正の拡張不確かさは $0.058 \%\left(\overline{q_{X}} / \overline{q_{A}}=0.08\right), 0.19 \%\left(\overline{q_{X}} / \overline{q_{A}}=0.02\right), 0.36 \%\left(\overline{q_{X}} / \overline{q_{A}}=0.01\right)$ であると見積もられ，主な不確か さ要因は流量計内の温度測定であった。これらの不確かさに比べ，標準值に対する減算法で得た K 值の相対偏差 は小さな值を示寸.さらに, 流量計の再現性を除いた流量計 A 及びBに起因する標準不確かさは $0.020 \%\left(\overline{q_{X}} / \overline{q_{A}}\right.$ $=0.08), 0.052 \%\left(\overline{q_{X}} / \overline{q_{A}}=0.02\right), 0.10 \%\left(\overline{q_{X}} / \overline{q_{A}}=0.01\right)$ であり, これらの值は, 実験で得られた図 6 の相対 偏差と良く一致する。このことは, 本研究で使用した試験ラインの温度, 圧力など試験条件や計測機器が不確か さ解析で用いられた值以上に安定したことを示唆する.しかしながら，これらの不確かさを評価せずに校正に伴 う不確かさを算出することは，不確かさを過小評価する危険性があると言える.

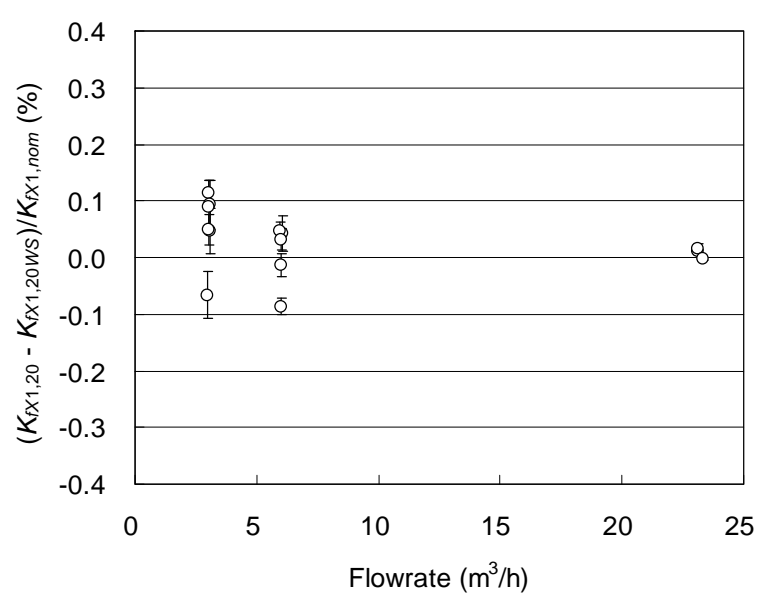

(a)

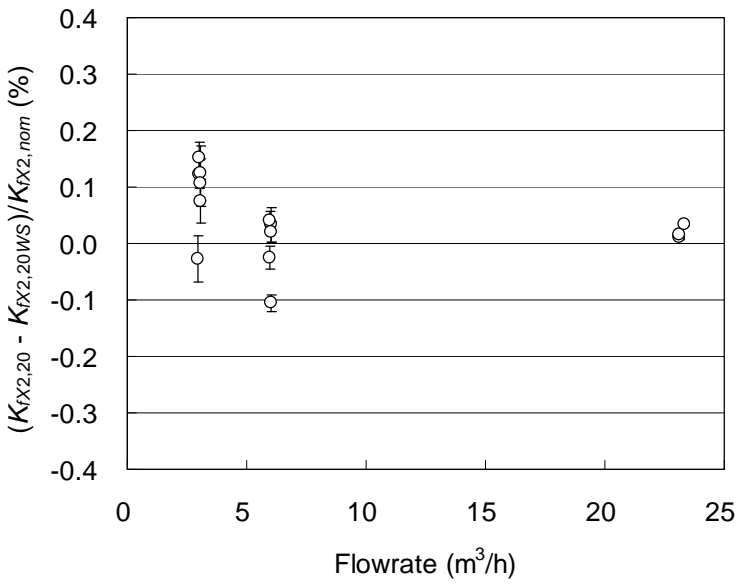

(b)

Fig. 6 Difference of $\mathrm{K}$ factors from the values obtained using the $1 \mathrm{t}$ weighing system of the primary standard. (a);flowmeter X1, (b);flowmeter X2. Each marker represents a mean value of reputation measurements. Each error bar indicates an experimental standard deviation of the mean. 


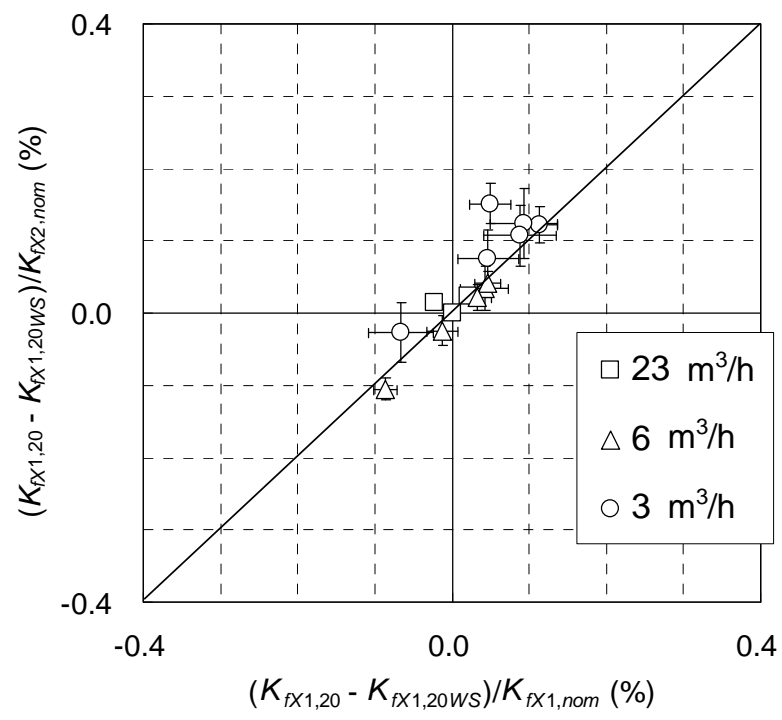

Fig. 7 Variation in K-factors of the flowmeter X2 against those of the flowmeter X1. Each error bar indicates the experimental standard deviation of the mean.

\section{6. 結 言}

本研究では，流量計を用いた流量減算法による流量計の校正の不確かさの推定を行い，校正の不確かさの妥当 性を国家標準設備を用いて実験的に検証した，その結果，校正值は不確かさの範囲内で一致することから，見積 もられた不確かさの妥当性が確認された。 さらに, 本研究で行った減算法による流量計の校正では, 不確かさの 主な要因が減算法に用いられる標準流量計の再現性と温度測定であることを明らかにした.

\section{文献}

(1) Lim, J., Yoon, B., Jang, S., Choi, H., and Park, K.. "Step-down procedure of sonic nozzle calibration at low Reynolds numbers”, Flow Measurement and Instrumentation, Vol. 21 (2010), pp. 340-346.

(2) Coleman, H.W. and Steele, W.G., "Experimentation and Uncertainty Analysis for Engineering”, 2nd Ed., John Wiley \& Sons, Inc., (1999).

（3）今井秀孝, 計測における不確かさの表現ガイド，財団法人,日本規格協会, (1996)

(4) 嶋田隆司, 土井原良次, 寺尾吉哉, 高本正樹, “国家標準としての石油大流量校正設備の開発”, 日本機械学会論文 集 B 編，Vol. 71, No. 703 (2005), pp.854-861.

(5) 嶋田隆司, 土井原良次, 武田一英, 寺尾吉哉, 高本正樹, “石油大流量校正設備の不確かさ解析（第 1 報, 流量計測 に対する不確かさ解析)”，日本機械学会論文集 B 編，Vol. 71, No. 712 (2005), pp.2956-2963.

(6) ISO 7278-3, "Liquid hydrocarbons - Dynamic measurement - Proving systems for volumetric meters - Part 3: Pulse interpolation techniques", (1998)

(7) Mattingly, G. E., Fluid Machanics Measurement, edited by R.J. Goldstein, Hemisphere Publishing Corporation, Washington, New York, London, (1983), pp.245-306

(8) ISO 9770, "Crude petroleum and petroleum products - Compressibility factors for hydrocarbons in the range $638 \mathrm{~kg} / \mathrm{m}^{3}$ to 1 074 kg/m", (1989) 